\title{
University Education in the United States.
}

THE Washington Bureau of Education has just issued Bulletin No. 87, dealing with certain statistics of State universities and colleges in the United States of America for the year ended June 30, 19r9. This is an annual publication which was formerly prepared and published by the National Association of State Universities, and contains data relating to ninety-two public institutions of university rank. The total enrolment in these State institutions for the year 1917-18 was 110,900 , as against 244,23 I in the corresponding private institutions. In 1918-19 the lowest enrolment was 3I for the New Mexico School of Mines, and the highest 8857 for the University of Michigan. With regard to teaching staff, the numbers in the State institutions vary from 7 to 908 , the latter being the number of teachers in the University of Minnesota in 1918-19. It is curious to find that the University of Michigan with its 8857 enrolments shows an average of 20 regular term students per teacher, while the University of Minnesota with an enrolment of 6095 has an average of only 7. What is perhaps more curious is the fact that the total working income of the former is $3,069,587$ dollars, while that of the latter is $3,462,36 \mathrm{I}$ dollars.

The fact that the institutions to which the bulletin has reference are passing through a stage of financial stringency very similar to that which is being experienced by the British universities at the present time gives an added interest to the publication. In the American State universities, just as in this country, "the cost of salaries has not risen to the same extent as the cost of living," and, as the bulletin very pertinently says, "unless the people wish to see their higher institutions staffed with men of inferior ability, it will be necessary to pay salaries sufficiently large to attract teachers of merit and ability." University teachers in this country will recognise a familiar ring about this language! The bulletin contains a mass of statistics which have been compiled by the Bureau of Education in the hope that they will be "very useful in the promotion of State campaigns for the more adequate support of higher education." While one may express the hope that American State universities and colleges will receive such public support in the future as will be necessary for their develop. ment, it should be observed that already they receive in the aggregate almost 73 per cent. of their income from public funds. In four States, indeed, the percentage is more than 9o. In this country, notwithstanding the recent additional grant of $500,000 l$. to the universities, State aid is greatly inferior to the State aid which is given to public institutions in America.

Of special interest is the question of students' fees in these universities and colleges. At the outset one must make a clear distinction between public and private universities or colleges in America. The number of students enrolled in the public higher institutions amounts to about $3 \mathrm{I}$ per cent. of the whole, while the remaining 69 per cent. are enrolled in private or non-State-aided institutions. As a rule, the former pay small fees. In the case of New York University the income from fees is as low as 3 per cent. of the total income. The average for the whole country in I9I7-18 was 22 per cent. of the total income. In the private institutions the percentage for the same year varied between $\mathrm{r} 7$ (Connecticut) and 87 (Alabama), with an average of 54 per cent., the remaining income being derived mainly from "productive funds" or private benefactions. So far as the State institutions are concerned there is no indication that students' fees, though lower than those in this country, are to be increased. The campaign to increase the income is apparently to be directed to obtaining increased assistance from public or State funds. The plea for State aid is concisely expressed in the words:-"When the State appropriates money to education, it is making a wise invest. ment which will yield manifold returns. Liberal support of higher education is good public economy and wise forethought for the future." One may be allowed to hope that the Government of this country will ponder over these words. Our home universities are sadly in need of further State aid.

\section{Recent Work on Minerals and Rocks.}

$\mathrm{N}^{\text {ow }}$ W that questions of crystal structure and of approximate isomorphism play so large a part in chemical and physical conceptions, the study of crystallography is no longer for specialists alone. Students of many branches of science will welcome the re-issue of J. B. Jordan's nets for making models of simple crystal-forms (T. Murby and Co., London, $3 s$.$) . The older names can be covered by labels$ bearing those suggested in this edition, though we should like to see "bipyramid" substituted for "pyramid" throughout, since no true pyramids, such as those occurring in tourmaline, are utilised. These models were familiar in the Royal School of Mines forty years ago, and should now. serve many future generations of students whose outlook on crystals has widened with physical research. Their effective colours and their price certainly commend them.

A. D. Hall provides a very interesting memoir (Union of South Africa Geol. Survey, No. I5, I920, $7 s$. 6d.) on "Corundum in the Northern and Eastern Transvaal," in which the modes of occurrence and of working are fully illustrated. The author, in a chapter on "The Problem of Genesis," very properly directs attention to the tardy recognition of corundum as a rock-forming mineral, and lays stress No. 2703 , VOL. 107$]$ on the experimental work of Morozewicz in 1899 . Corundum in the Transvaal arises from a granite magma supersaturated with alumina. Hall holds that this supersaturation arises, not through absorption of aluminous material from contact-rocks, but by removal of silica into those rocks along the zones of contact.

In "Phosphate in Canada" (Canada Depart. of Mines, No. 396, I920) Hugh S. Spence describes and illustrates the well-known occurrences of apatite in Ontario and Quebec, and discusses works established in other parts of Canada where imported phosphatic materials are used. The apatite " is to be considered of igneous origin rather than to have been derived from the original limestones" through which the pegmatite masses have passed. The associated minerals, such as pyroxene, scapolite, and phlogopite, are described. At Huddersfield, Quebec, allanite occurs in crystals more than an inch in diameter, and fluorspar, which is here abundant in calcite, assumes a deeper violet colour in close proximity to it. An emanation-influence naturally suggests itself.

The minerals of saline lakes, notably epsomite, are dealt with by L. Reinecke in "Mineral Deposits between Lillooet and Prince George, British Columbia" 